\title{
REFLECTIONS
}

\section{Creative Writing Contest Honorable Mention}

\section{GO WITH ME}

When the doctor said, Sorry,

You have only six months, he

Went straight home, gathered

his favorite things: chocolate

covered cherries, mixed nuts,

Lucky strikes, ashtrays-

rigged the television screen

to the computer-settled

into his chestnut lazy boy

with the pivoting pedestal,

puffed into a four decade

shroud of smoke, played chess.

Placed knights, bishops, rooks

with calculated complexity,

categorically shielding the king.

With inescapable checkmate

in sight, he clasped my hand

pleading, Go with me.

You know I can't do that,

I whispered.

Gripping my hand,

As if-he were

falling, searching

my face,

You can go part way,

- and come back.

Standing watch

amid alternating

dark and light squares,

that's what I did.

Our Honorable Mention poems demonstrate the wonderful variety of medical poetry. "Go With Me" presents an unforgettable scene of a man externally facing death with a tough veneer, his "four decade/ shroud of smoke," but from within the smoke comes the voice of a vulnerable human being who pleads, "Go with me ... part way/and come back." And we see the remarkable gift of love that shines as the poem ends-"that's what I did." 